\title{
Mitigating California Wildfire Impact Through Zoning and Housing Policy
}

\section{Conner S. Philson ${ }^{1}$, Lauren Wagner ${ }^{2}$, Ria Nawathe ${ }^{3}$}

${ }^{1}$ University of California, Los Angeles, Department of Ecology and Evolutionary Biology, Los Angeles, CA ${ }^{2}$ University of California, Los Angeles, Neuroscience Interdepartmental Program, Los Angeles, CA 3University of California, Los Angeles, Department of Psychology, Los Angeles, CA https://doi.org/10.38126/ISPG180112 Corresponding author: cphilson@ucla.edu

Keywords: wildfire; housing crisis; climate adaptation; urban-wildland interface; up-zoning; buyout

Executive Summary: Since 1970, California has been facing the worst affordable housing crisis in the United States. In an attempted solution, government subsidies have driven housing development into untouched wildlands across the state. However, these developments are increasingly subject to destruction by wildfire due to global climate change and historical mismanagement of public lands. Since 1990, 41\% of new housing across California has been developed in known fire zones. Wildfire prevention, combat, and damage costs approximately $\$ 18$ billion annually, with $\$ 10$ billion attributed to property damage. During 2020, California's worst fire year on record, more than 4.4 million acres burned with costs to personal property estimated to exceed $\$ 20$ billion. Therefore, residential zoning and housing policy are critical components to mitigate wildfire impact. To do so, we propose the implementation of a multipronged approach over the next decade: discontinue development in extremely high-risk fire zones, increase government buyouts in these high-risk areas to move people out of harm's way, increase urban up-zoning to generate affordable housing, and increase retrofitting of existing at-risk homes to enhance structural and resident survival. This will be a historic economic, legislative, and logistic undertaking. However, despite the large up-front costs, an estimated $\$ 350$ billion and 1,500 lives can be saved over the next decade through this approach. The consequences to life and property because of wildfire in California are too great for inaction or incremental progress. Swift and foundational change is required over the coming decade.

\section{Statement of issue}

From 2016-2020, California wildfires have cost approximately $\$ 18$ billion annually (CDOI 20162019; Fann et al. 2018; CCST 2020). Of this, $\$ 3$ billion in state and federal funds are spent on firefighting costs and another $\$ 5$ billion on prevention. The remaining $\$ 10$ billion is incurred by personal property damage to individuals and businesses. However, quantifying the comprehensive cost of wildfires across the state is unachievable with current data, and when incorporating the loss of ecosystem services and public health impacts, annual costs are estimated to sharply rise (Lueck \& Yoder 2016; CCST 2020).
From 1987 to 2003, the western US experienced a 6fold increase in burned forest area, as compared to the previous 16 years; a phenomenon that can be largely attributed to global climate change (Westerling et al. 2006; Hessl 2011; Abatzoglou \& Williams 2016; Davis 2018; Stevens-Rumann et al. 2018). This trend has worsened in recent years, and in 2020 California saw five of the six largest fires in state history with 4,257,863 total acres burned (Calfire 2020). Resulting property damages in 2020 are estimated around $\$ 20$ billion dollars, double the average of the prior four years (Cowan 2020; Legislative Analyst's Office 2020).

Given the increase in severity and scope of climate change in recent years, wildfires are expected to 
become more destructive and wide-reaching (Westerling et al. 2006; Abatzoglou \& Williams 2016; Davis 2018; Stevens-Rumann et al. 2018). As property damage is the largest personal and economic cost of wildfire, adapting residential zoning and development policies is critical to adapting to climate change and preserving life and property across California.

$82 \%$ of building destruction by California wildfires occurs at the urban-wildland interface-where houses and buildings meet vegetation and wildlands-with more than half of these buildings located in areas at risk for wildfire (Keeley 1993; Rundel \& King 2001; Radeloff et al. 2005; Kramer et al. 2019). Historic zoning laws have enabled the expansion of suburban developments into previously undeveloped land (Radeloff et al. 2018). Despite the potential for wildfire damage on California's urbanwildland interface having been recognized for decades, from 1990 to 2010 41\% of new homes in California were built in fire vulnerable areas (Keeley 1993; Rundel \& King 2001).

A key contributor to fire damage risk is that nearly all new housing developments are designated for single family homes (Gude et al. 2018), resulting in a high number of structures separated by natural landscape features (e.g., trees and green spaces). Inexpensive home construction typically uses combustible wooden frames (Syphard et al. 2019), and wildfire is able to rapidly spread between structures via grass yards and trees (Syphard et al. 2013). While some risk-mitigating policies are in place, many were only enacted recently. AB 3074, passed in September 2020, requires five feet of foliage-free defensible space around structures in specified high-fire hazard areas. However, even this stipulation will not adequately address the increasing intensity and speed of California wildfire spread, as estimates of adequate space are closer to 58 feet (Syphard et al. 2014). Though the costly consequences of developing housing in high-fire hazard areas are well known, new housing zones continue to be granted in firehazardous areas statewide.

Residential expansion is largely due to California's affordable housing crisis, which dates back to the 1970's. Although 100,000 homes are built annually, an estimated 100,000 more are needed to keep up with demand (Legislative Analyst's Office 2015).
While a number of bills have been proposed to mitigate the housing crisis by focusing on urban development (e.g. SB-2 and SB-25 in 2017, and SB-50 and SB-872 in 2018), the state continues to subsidize the expansion of single-family housing into known high fire-hazard areas as a solution to the housing crisis-despite the evidence of its consequences.

California will face the interwoven crises of global climate change and affordable housing shortages until adequate solutions are implemented. While solutions to the housing crisis are not straightforward, legislators must ensure that housing policy does not challenge known and highly destructive burn patterns. Expanding development into known fire areas-the state's current solution to the housing crisis - costs billions of dollars in damage every year and increases risk to the lives and wellbeing of its citizens (Kochi et al. 2010; Syphard et al. 2013). The growing inefficacy and costs associated with reactionary firefighting and rescue strategies highlight the need for more proactive approaches to combating natural disasters (Freudenberg et al. 2016). To adapt to the new normal of climate change, new housing and development policy must mitigate the extreme costs of wildfire while not contributing to the affordable housing crisis.

\section{Policy options}

i. Option 1: Discontinue development in high firehazard zones

While development on the urban-wildland interface may buffer California's housing crisis, the consequences of wildfire damage currently outweigh this advantage. Costs are expected to grow by billions of dollars annually, property owners will be displaced from their homes as they are destroyed, and firefighters often must focus on structural defense and rescue rather than active firefighting. Discontinuing development in high fire-hazard zones can mitigate further worsening the current issues and save homeowners $\$ 10$ billion annually (CCST 2020).

\section{Advantages}

Would prevent an increase of homes highly susceptible to fire, allowing for time for other policy options to be implemented without worsening the current situation and accruing further costs. 


\section{Disadvantages}

Without alternatives in place, discontinuing development in high fire-hazard zones may further worsen the housing crisis and raise the price of existing homes, requiring more immediate and potentially costly alternatives to be implemented to buffer homelessness.

\section{ii. Option 2: Up-zoning in urban areas}

Up-zoning-altering zoning codes to permit denser housing structures-in low fire risk areas, such as cities, has been championed as a strategy to increase housing availability and affordability in urban areas (Crump et al. 2019, Bliss 2019). Building multi-family dwellings within existing urban settlements also geographically insulates residents from wildfire hazard zones, mitigating wildfire destruction potential.

A large percentage of California's residential land is zoned exclusively for single-family dwellings (37\% in San Francisco; 75\% in Los Angeles; 80\% statewide; Badger \& Bui, 2019; Radulovich 2018). This leaves significant room for urban development and reflects historical zoning trends that favor suburbia (Morrow 2013).

In January 2020, California's most recent attempt at up-zoning, SB-50, was struck down. SB-50 proposed altering local zoning restrictions near public transit and job centers to allow residential structures with 15 additional stories in urban areas, depending on local population and the ability for these multiplex housing units to be developed (Keeling 2019). Critics argued that SB-50 would cause gentrification by favoring new luxury units and that solely increasing housing supply through up-zoning would not ameliorate California's housing crisis (Lowrey 2020; Nichols 2020). However, increasing market-rate housing supply can lead to price stability and decrease future rents by up to $7 \%$ (Asquith et al. 2020). Additionally, gentrification can be mitigated by requiring that at least half of new developments be "market-rate" (compared to 25\% in SB-50).

\section{Advantages}

Up-zoning to allow for multi-family structures in current single-family zones can mitigate both California's affordable housing crisis and demand for development in high-risk fire zones, reducing injury and destruction of property and protecting wildlands from further development.

\section{Disadvantages}

Health effects of increased urban density (e.g., air and noise pollution) would need to be addressed.

\section{iii. Option 3: Increase property buyouts}

Property buyouts, whereby at-risk properties are purchased to remove people from risky areas, is increasingly being considered as a long-term preventative strategy for destruction caused by natural disasters (Siders 2019; Migaud 2020). Financed via local, state, and federal funds, programs such as FEMA's Hazard Mitigation Assistance program compensate property owners at marketvalue for their land and structures (FEMA 2007; 2017). Property buyouts have been successfully leveraged as risk-management strategies in flood zones (FEMA 2009; Polefka 2013; White 2011; FEMA 2011), and since 1993 FEMA has acquired more than 40,000 at-risk properties in 49 states and 3 U.S. territories for $\$ 2$ billion (Dabson \& JimenezMagdaleno 2017; Rosenstiel School of Marine and Atmospheric Science 2019; Mach et al. 2019).

While buyouts have improved damage mitigation across the country, such preventative land use planning has not been applied in California's wildfire approach (CCST 2020). Rather, efforts have focused on fire suppression activities (e.g., fighting wildfires more rapidly and with more manpower) that are far more expensive in the long-term (McQuillan et al. 2019). The acquisition of properties in high firehazard areas, particularly in repetitive-loss communities and those without suitable evacuation routes, will significantly minimize destruction to property and life (CCST 2020; Syphard et al. 2012; Syphard \& Keeley 2019).

\section{Advantages}

Buyouts move people out of harm's way. FEMA's buyout program has saved an estimated $\$ 153$ billion by mitigating disaster-recovery expenses and property and tax loss (Polefka 2013; FEMA 2005). Additional benefits include rewilding of wildlife habitats and/or potential creation of public recreational spaces (Polefka 2013). 


\section{Disadvantages}

Success of property buyouts depends on the willingness of owners to sell their homes and the availability of affordable housing for relocation. Additionally, buyouts are a large up-front expense, requiring major budget reallocations to allow future economic benefits to outweigh these up-front costs. The loss of property tax, a major revenue source, from acquired properties may substantially depress local budgets (Georgetown Climate Center 2020; Ruppert et al. 2018). Destruction of bought-out properties can also be expensive whereas undestroyed properties can still facilitate fire spread.

iv. Option 4: Enhance fire safety standards in high firehazard zones

Losses from wildfires are typically attributed to the presence of wildland fuel-trees, dried vegetation, etc.-on or near the wildland-urban interface (Schoennagel 2009). Although efforts to mitigate wildfire impact through fuel management strategies (controlled burns and vegetation clearing) have historically been promoted as preventative measures (Pollet \& Omi 2002; Martinson \& Omi 2008; Schoennagel 2009), structural characteristics can also significantly predict damage risk (FEMA 2008; Syphard et al. 2013). Factors affecting risk include:

\section{Structure arrangement and location}

Housing in small, isolated clusters with low to intermediate density on the edge of developments and single-family homes are most susceptible to destruction due to interspersed vegetation and impaired firefighter access (Syphard et al. 2013 \& 2017)

\section{Building material}

Double-paned windows (Cuzillo \& Pagni 1998; Syphard et al. 2013), vinyl window frames, tile roofs, and stucco exteriors (Syphard et al. 2017) best predict successful structural survival

\section{Defensible space}

Vegetation around a structure increases the likelihood of damage or destruction. AB 3074 recently increased the required amount of defensible space to $5 \mathrm{ft}$ without vegetation (Office of the Governor 2020); however, Federal Emergency Management Agency (hereafter, FEMA) recommends 30ft (FEMA 2008) and optimal defensible space may be up to 58ft (Syphard et al. 2014)
New structures in high fire-hazard zones should require at least $30 \mathrm{ft}$ of defensible space and building materials should comprise the aforementioned fireresistant materials. Existing structures should be retrofitted with the same guidelines whenever possible, potentially encouraged through informational campaigns, legal mandates, or government subsidies. Residents in high fire-hazard zones should also be mandated to review educational wildfire safety programs, such as those offered by FEMA.

\section{Advantages}

Would reduce fire destructivity, enhance the structural longevity, and mitigate financial losses to individuals and businesses.

\section{Disadvantages}

Retrofits are expensive, increasing defensible space requires land, and no amount of optimal space or fireresistant technology can wholly ensure structural survival. Subsidies for retrofitting and increased public and private technological investment and development of fire-resistant materials can help offset some disadvantages of this option.

\section{Policy recommendation}

Based on current and projected fire patterns across California and the need for affordable housing in firesafe locations, we recommend that all policy options be implemented in a multipronged approach over the coming decade in the following order based on ease of implementation and short-term benefits:

1) Housing development in the most at-risk fire hazard zones should be discontinued immediately, and development in moderate-risk areas gradually phased out (Option 1)

2) Up-zoning policies should be implemented in urban areas to allow density increases from single-family dwellings to market-rate multi-unit structures, providing affordable housing in fire-safe areas and mitigating the need for further urban-wildland development (Option 2)

3) Buyout programs to purchase property destroyed in repeated burn areas, and to 
preemptively purchase in the highest-risk zones (Option 3)

4) For property owners who do not participate in buyout programs, retrofitting of pre-existing homes in atrisk areas with fire safety mechanisms should be encouraged, subsidized, or legally required. Enhanced safety standards should be mandated for all new developments (Option 4)

\section{References}

Abatzoglou, John T., and A. Park Williams. 2016. "Impact of anthropogenic climate change on wildfire across western US forests." Proceedings of the National Academy of Sciences 113:11770-11775. https://doi.org/10.1073/pnas.1607171113

Asquith, Brian, Evan Mast, and Davin Reed. 2019. "Supply Shock Versus Demand Shock: The Local Effects of New Housing in Low-Income Areas." Upjohn Institute for Employment Research. https://doi.org/10.17848/wp19-316

Badger, Emily, and Quoctrung Bui. 2019. "Cities start to question an American ideal: A house with a yard on every lot." New York Times. https://www.nytimes.com/interactive/2019/06 118/upshot/cities-across-america-questionsingle-family-zoning.html

Bliss, Laura. 2019. "Oregon's Single-Family Zoning Ban Was a "Long Time Coming" CityLab. https://www.bloomberg.com/news/articles/201 9-07-02/upzoning-rising-oregon-bans-singlefamily-zoning

Burnett, Richard, Hong Chen, Mieczysław Szyszkowicz, Neal Fann, Bryan Hubbell, C. Arden Pope, Joshua S. Apte et al. 2018. "Global estimates of mortality associated with long-term exposure to outdoor fine particulate matter." Proceedings of the National Academy of Sciences 115:9592-9597. https://doi.org/10.1073/pnas.1803222115

California Department of Forestry and Fire Protection (CAL FIRE). 2020. "Stats and Events." Cal Fire Department of Forestry and Fire Protection. State of California. https://www.fire.ca.gov/statsevents/

California Department of Insurance (CDOI). 2016. "Valley and Butte Fires Cause an Estimated \$1 Billion in Insurance Losses." News release, January 25, 2016. California Department of Insurance. https://www.insurance.ca.gov/0400news/0100-press-releases/archives/release009$\underline{16 . \mathrm{cfm}}$
While land zoning reform and fire damage mitigation will be highly expensive and logistically challenging, the destructive potential of California wildfires is too great for inaction or incremental progress. Swift and foundational change is required over the coming decade to adapt to the worsening effects of climate change and mitigate impacts to life and personal property. More than $\$ 350$ billion and 1,500 lives can be saved over the next decade (based on current costs and estimates) by implementing the recommended policy options (Burnett et al. 2018; CCST 2020; Fann et al. 2018).

California Department of Insurance (CDOI). 2017. "Insured Losses from October Wildfires Top \$3 Billion Statewide." News release, October 31, 2017. California Department of Insurance. http://www.insurance.ca.gov/0400-news/0100press-releases/archives/release118-17.cfm

California Department of Insurance (CDOI). 2018. "Insurance Commissioner Reports over \$9 Billion Insured Losses from Deadly 2018 Wildfires." News release, December 12, 2018. California Department of Insurance. http://www.insurance.ca.gov/0400-news/0100press-releases/2018/release142-18.cfm

California Department of Insurance (CDOI). 2019. "Wildfire Insurance Losses from November 2018 Blazes Top \$12 Billion." News release, May 8, 2019. California Department of Insurance. http://www.insurance.ca.gov/0400-news/0100press-releases/2019/release041-19.cfm

Cowan, Jill. 2020. "How Much Will the Wildfires Cost?" The New York Times, September 16, 2020. https://www.nytimes.com/2020/09/16/us/calif ornia-fires-cost.html

Crump, Sarah, Jenny Schuetz, Trevor Mattos, and Luc Schuster. 2020. "Zoned Out: Why Massachusetts Needs to Legalize Apartments Near Transit." https://www.bostonindicators.org/reports/repo rt-website-pages/zoned-out

Cuzzillo, Bernard R., and Patrick J. Pagni. 1998 "Thermal breakage of double-pane glazing by fire." Journal of Fire Protection Engineering 9:1-11. https://doi.org/10.1177/104239159800900101

Dabson, Brian, and Karla Jimenez-Magdaleno. 2017. "FEMA-Funded Property Buyouts: The Impacts on Land and People." https://ncgrowth.unc.edu/wpcontent/uploads/2018/01/Buyouts Impact Lite ratureReview Final.pdf 
Davis, Kimberley T., Philip E. Higuera, and Anna Sala. 2018. "Anticipating fire-mediated impacts of climate change using a demographic framework." Functional Ecology 32:1729-1745. https://doi.org/10.1111/1365-2435.13132

Fann, Neal, Breanna Alman, Richard A. Broome, Geoffrey G. Morgan, Fay H. Johnston, George Pouliot, and Ana G. Rappold. 2018. "The health impacts and economic value of wildland fire episodes in the US: 2008-2012." Science of the total environment 610:802-809.

https://doi.org/10.1016/j.scitotenv.2017.08.024

FEMA. 2007. "Mitigation's Value to Society." Homeland Security Digital Library. United States Federal Emergency Management Agency, 2007. https://www.hsdl.org/?abstract\&did=480585

FEMA. 2008. "Home Builder's Guide to Construction in Wildfire Zones." United States Federal Emergency Management Agency, 2008. https://www.ready.gov/sites/default/files/2020 -03/home-builder -guide-constructiondefensible-space.pdf

FEMA. 2009. "Loss Avoidance Study: Eastern Missouri, Building Acquisition, Part One: General Overview." United States Federal Emergency Management Agency, 2009. https://www.fema.gov/casestudy/loss-avoidance-study-eastern-missouribuilding-acquisition

FEMA. 2011. "Mitigation Best Practices." United States Federal Emergency Management Agency. http://nhma.info/uploads/bestpractices/2011\% 20-\%20Best $\% 20$ Practices $\% 20-\% 20$ Acquisitions \%20Buyouts.pdf

FEMA. 2017. "Frequently Asked Questions: Property Acquisitions for Open Space." United States Federal Emergency Management Agency. https://hallways.cap.gsa.gov/app/\#/doclib?docu ment $=8039$

Freudenberg, Robert, Ellis Calvin, Laura Tolkoff, and Dare Brawley. 2016. "Buy-in for buyouts: The case for managed retreat from flood zones". Cambridge, MA: Lincoln Institute of Land Policy. https://www.lincolninst.edu/sites/default/files/ pubfiles/buy-in-for-buyouts-full.pdf

Georgetown Climate Center. 2020. "Managed Retreat Toolkit - Voluntary Buyouts." Georgetown Law. https://www.georgetownclimate.org/adaptation toolkits/managed-retreat-toolkit/voluntarybuyouts.html

Gude, Patricia, Ray Rasker, and Jeff Van Den Noort. 2008. "Potential for future development on fire-prone lands." Journal of Forestry 106:198-205. https://doi.org/10.1093/jof/106.4.198

Hessl, Amy E. 2011. "Pathways for climate change effects on fire: Models, data, and uncertainties." Progress in Physical Geography 35:393-407. https://doi.org/10.1177/0309133311407654
Keeley, Jon E. 1993. "Interface between ecology and land development in California." In Symposium The Interface Between Ecology and Land Development. Southern California Academy of Sciences. https://pubs.usgs.gov/of/2000/of00-062/

Keeling, Brock. 2019. "SB 50 Flowchart Will Help You Make Sense of California's Transit-Housing Bill." Curbed SF. VOX Media, April 29, 2019. https://sf.curbed.com/2019/4/29/18518339/sb -50-flowcart-californias-transit-housing-bill

Kochi, Ikuho, Geoffrey H. Donovan, Patricia A. Champ, and John B. Loomis. 2010 "The economic cost of adverse health effects from wildfire-smoke exposure: a review." International Journal of Wildland Fire 19:803-817. https://doi.org/10.1071/wf09077

Kramer, Heather Anu, Miranda H. Mockrin, Patricia M. Alexandre, and Volker C. Radeloff. 2019. "High wildfire damage in interface communities in California." International journal of wildland fire 28:641-650. https://doi.org/10.1071/wf18108

Legislative Analyst's Office. 2020. "State Wildfire Response Costs Estimated to Be Higher Than Budgeted". Sacramento, CA: Legislative Analyst's Office. https://lao.ca.gov/Publications/Report/4285

Lowrey, Annie. 2020. "The Bill That Could Make California Livable Again." The Atlantic. Atlantic Media Company, January 13, 2020. https://www.theatlantic.com/ideas/archive/202 0/01/sb50-california/604786/

Lueck, Dean, and Jonathan K. Yoder. 2016. "Clearing the smoke from wildfire policy: An economic perspective".

PERC.

https://www.perc.org/2016/07/21/clearingthe-smoke-from-wildfire-policy-an-economicperspective/

Mach, Katharine J., Caroline M. Kraan, Miyuki Hino, A. R. Siders, Erica M. Johnston, and Christopher B. Field. 2019. "Managed retreat through voluntary buyouts of flood-prone properties." Science Advances 5:eaax8995. https://doi.org/10.1126/sciadv.aax8995

Martinson, Erik J., and Philip N. Omi. 2008. "Assessing mitigation of wildfire severity by fuel treatmentsan example from the Coastal Plain of Mississippi." International Journal of Wildland Fire 17:415-420. https://doi.org/10.1071/wf06067

Migaud, Michael. 2020. "Property Buyouts After Natural Disasters: The Economic Implications for Texas Residents." The Takeaway 11:2 https://bush.tamu.edu/wpcontent/uploads/2020/05/V112 Texas Lyceum Housing Takeaway.pdf 
Morrow, Greg. 2013. The Homeowner Revolution: Democracy, Land Use and the Los Angeles SlowGrowth Movement, 1965-1992. Dissertation: University of California, Los Angeles. https://escholarship.org/uc/item/6k64g20f

Nichols, Chris. 2020. "PolitiFact - Fact or Fiction? A Look At Claims About SB 50, One Of California's Most Controversial Housing Bills." PolitiFact. Poynter Institute, January 21, 2020. https://www.politifact.com/article/2020/jan/21 /fact-or-fiction-look-claims-about-onecalifornias-/

Office of the Governor. 2020. https://www.gov.ca.gov/wpcontent/uploads /2020/09/AB-3074.pdf

Polefka, Shiva. 2013. "Moving Out of Harm's Way." Center for American Progress. https://www.americanprogress.org/issues/gree n/reports/2013/12/12/81046/moving-out-ofharms-way/

Pollet, Jolie, and Philip N. Omi. 2002 "Effect of thinning and prescribed burning on crown fire severity in ponderosa pine forests." International Journal of Wildland Fire 11:1-10. https://doi.org/10.1071/wf01045

Radeloff, Volker C., David P. Helmers, H. Anu Kramer, Miranda H. Mockrin, Patricia M. Alexandre, Avi Bar-Massada, Van Butsic et al. 2018. "Rapid growth of the US wildland-urban interface raises wildfire risk." Proceedings of the National Academy of Sciences 115:3314-3319. https://doi.org/10.1073/pnas.1718850115

Radeloff, Volker C., Roger B. Hammer, Susan I. Stewart, Jeremy S. Fried, Sherry S. Holcomb, and Jason F. McKeefry. 2005. "The wildland-urban interface in the United States." Ecological applications 15:799805. https://doi.org/10.1890/04-1413

Radulovich, Tom. 2018. "Rethinking Residential Zoning." Livable City. Livable City. https://www.livablecity.org/rethinking-rh/

Rundel, P. W., and J. A. King. 2001. "Ecosystem processes and dynamics in the urban/wildland interface of Southern California." Journal of Mediterranean Ecology 2:209-220

Ruppert, Thomas, John Fergus, and Enio Russe-Garcia. 2018. "Managing Property Buyouts at the Local Level: Seeking Benefits and Limiting Harms." Environmental Law Reporter News \& Analysis 48:10520. https://www.flseagrant.org/wpcontent/uploads/ELR-final-pdf.pdf

Schoennagel, Tania, Cara R. Nelson, David M. Theobald, Gunnar C. Carnwath, and Teresa B. Chapman. 2009. "Implementation of National Fire Plan treatments near the wildland-urban interface in the western United States." Proceedings of the National Academy of Sciences 106:10706-10711. https://doi.org/10.1073/pnas.0900991106
Siders, A. R. 2019. "Managed retreat in the United States." One Earth 1:216-225. https://doi.org/10.1016/i.oneear.2019.09.008

Stevens-Rumann, Camille S., Kerry B. Kemp, Philip E. Higuera, Brian J. Harvey, Monica T. Rother, Daniel C. Donato, Penelope Morgan, and Thomas T. Veblen. 2018. "Evidence for declining forest resilience to wildfires under climate change." Ecology letters 21:243-252. https://doi.org/10.1111/ele.12889

Syphard, Alexandra D., and Jon E. Keeley. 2019. "Factors Associated with Structure Loss in the 2013-2018 California Wildfires." Fire 2:49. https://doi.org/10.3390/fire2030049

Syphard, Alexandra D., Avi Bar Massada, Van Butsic, and Jon E. Keeley. 2013. "Land use planning and wildfire: development policies influence future probability of housing loss." PloS one 8:e71708. https://doi.org/10.1371/journal.pone.0071708

Syphard, Alexandra D., Jon E. Keeley, Avi Bar Massada, Teresa J. Brennan, and Volker C. Radeloff. 2012. "Housing arrangement and location determine the likelihood of housing loss due to wildfire." PloS one 7:e33954.

https://doi.org/10.1371/journal.pone.0033954

Syphard, Alexandra D., Teresa J. Brennan, and Jon E. Keeley. 2014. "The role of defensible space for residential structure protection during wildfires." International Journal of Wildland Fire 23:11651175. https://doi.org/10.1071/wf13158

Syphard, Alexandra D., Teresa J. Brennan, and Jon E. Keeley. 2017. "The importance of building construction materials relative to other factors affecting structure survival during wildfire." International journal of disaster risk reduction 21:140-147. https://doi.org/10.1016/j.ijdrr.2016.11.011

Taylor, Mac. 2015. "California's high housing costs: Causes and consequences." Sacramento, CA: Legislative Analyst's Office. https://homeforallsmc.org/wpcontent/uploads/2017/05/housing-costs.pdf

Westerling, Anthony L., Hugo G. Hidalgo, Daniel R. Cayan, and Thomas W. Swetnam. 2006. "Warming and earlier spring increase western US forest wildfire activity." Science 313:940-943. https://doi.org/10.1126/science.1128834

White, Esther. 2011. "Establishing long-term cost effectiveness of fema buyouts: A loss avoidance study of the acquisition/demolition of 22 properties in Shepherdsville, Kentucky". https://uknowledge.uky.edu/cgi/viewcontent.cgi $\underline{\text { ?article }=1105 \& \text { context }=\text { mpampp etds }}$ 
Conner S. Philson is a Ph.D. Student in Ecology and Evolutionary Biology at UCLA studying the evolution and consequences of social behavior using the yellow-bellied marmot population at the Rocky Mountain Biological Laboratory (RMBL) in Colorado. His science policy work focuses on combating climate change, environmental degradation, and loss of biodiversity by communicating science to voters and policy makers. He plans to pursue a career in science policy/diplomacy.

Lauren Wagner is a doctoral student of Neuroscience at the University of California, Los Angeles, where she uses fMRI, genetics, and behavior to understand the neural bases of language development. She is currently the Secretary of the Science Policy Group at UCLA and is interested in science diplomacy and linguistic equity within the global scientific sphere. Lauren received her bachelor's degrees in Neuroscience and Linguistics from the University of Texas at Austin.

Ria Nawathe is a pre-medical undergraduate student at the University of California, Los Angeles, where she is majoring in Psychobiology. Her research work has involved studying the molecular mechanisms behind microgravity-induced skeletal muscle atrophy using 'omics and cell culture models at NASA's Ames Research Center. Currently, she is a member of the Science Policy Group at UCLA and is interested in the intersection of policy and social justice. 